AWEJ for Translation \& Literary Studies, Volume3, Number3. August 2019 DOI: http://dx.doi.org/10.24093/awejtls/vol3no3.6

\title{
Critical Stylistic analysis of the Concept of Extremism in DeLillo's Falling Man (2007)
}

\author{
Harir Aamer Ahmed \\ College of Education for Women, \\ University of Baghdad, Baghdad, Iraq \\ Nawal Fadhil Abbas \\ College of Education for Women, University of Baghdad \\ Baghdad, Iraq
}

\begin{abstract}
The increase in the number of terrorist attacks, especially the shocking event of 9/11 led to the wide coverage of topics such as terrorism and extremism. Such coverage is not only conveyed by the media and newspaper articles, but also by creating novels. As a result, the current study focuses on the concept of extremism. The hallmark of this study is to illustrate how such concept is ideologically embedded within a text. Thus, this study is confined to Don DeLillo's Falling man (2007). In this novel, DeLillo describes the trauma caused by 9/11 attacks. It is important to note that he recruits his language to mirror Islam as an extreme religion. To access the concept of extremism in this novel, the researchers will apply a critical stylistic approach. Therefore, the analysis will depend heavily on the textual conceptual model that is represented by Jeffries (2010) to uncover the hidden ideologies related to extremism. The aims of current study is to investigate the way the linguistic meaning is used as a vehicle for constructing the ideology of extremism in the selected novel; in addition to identify the textual meaning that underlies extremism in the selected novel. With the aid of critical stylistic tools, the researchers find out that DeLillo employs the use of certain linguistic choices in his novel. These choices tackle the concept of extremism focusing on the violent attitude behind such a concept with an attempt to link this concept to Islam and Muslims.

Keywords: 9/11 attacks, critical stylistics, extremism, Islam \& Muslims, terrorism

Cites as: Ahmed, H. A., \& Abbas, N. F. (2019). Critical Stylistic analysis of the Concept of Extremism in DeLillo's Falling Man (2007). Arab World English Journal for Translation \& Literary Studies, 3 (3) 82-106. DOI: http://dx.doi.org/10.24093/awejtls/vol3no3.6
\end{abstract}


AWEJ for Translation \& Literary Studies Volume, 3 Number 3. August 2019

Critical Stylistic analysis of the Concept of Extremism

Ahmed \& Abbas

\subsection{Introduction}

The terrorist attacks of 9/11 are imprinted in people's minds inside the United States and in the whole world in general. The shock of bombing of the World Trade Center was attributed to the socalled "Muslims" that led to numerous propagandas of depicting Islam as a religion of violence, struggle, and extremism. This view is widely held by mass media, press, and literature. The portrayal of the attacks has become part of the popular culture. On the one hand, the media and press have been covering the event, its causes, and its effects. On the other hand, the literary texts especially novels, have started to work on depicting the "the other'"or the so-called "Muslims". In one way or another, those Muslims are associated with the attacks, the reconstruction of American identity, and the consequences of the aftermath that arose fears of terror and extremism. While other novels attempt at dealing with the struggle of Muslims after the attacks. This kind of fiction makes its way to establish the era of post 9/11 novels that constitutes its own share within the American literature and the global literature in general.

As a matter of fact, 'extremism' as a concept has been studied from political, social, and psychological points of view. It lies at the heart of recent studies yet dealing with this concept in 9/11 novel from a critical point of view is the goal of this study. Thus, the present study will bridge the gap in literature by studying the linguistic choices and textual meanings that underlie extremism in the selected 9/11 novel. The study will be of value for the field of linguistics as it attempts at tackling the subject of extremism in literary texts. This will enrich the field of linguistics with new understandings of the language that is recruited by the writer to establish particular believes by using certain linguistic strategies.

It is significant to enrich the field of linguistics in general and critical studies in particular with a study that deals with the concept of extremism in literature. Also, it reveals the employment of this concept by the writer and how he portrays Muslims. Thus, it provides an understanding of the language of Falling Man. This is beneficial not only to linguistics but also to the field of literature by giving new insights about the concept of extremism.

\subsection{Background}

\subsubsection{9/11 Fiction}

The literature of $9 / 11$ is a mixture of representations of the event, mourning, trauma, globalization, the conflict of 'the other,' and most important the depiction of a world under terrorism and extremism. Away from literature, the event of bombing the twin towers of the World Trade Center is traumatic. This is due to the fact that many people died, and others suffered from the collapse of the towers because of losing family members, friends and loved persons. The towers are symbolic as they represent power and capitalism, and they are symbolic post their destruction as they represent grief and mourning memories. Some literature on the event covers issues of representing the reality and history of the event. Other works raise questions such as the war on the terror and the meaning of the event inside and outsides the U.S. with being cautious of misrepresentation or politicization of the event (Keniston \& Quinn, 2008). The literary works on 9/11 attacks varied between poetry, plays, and novels. Falling Man is one of such works.

Arab World English Journal for Translation \& Literary Studies 
AWEJ for Translation \& Literary Studies Volume, 3 Number 3. August 2019

It is not the only novel by DeLillo that tackles issues such as extremism and terrorism. It is one among other novels such as Mao II, The Names (1982) and White Noise (1985). DeLillo's previous novels also foreshadow the 9/11 attacks. This fact makes some critics to entitle DeLillo as a prophet, and he renounces such a description (Tsiokou, 2017).

DeLillo's works set themselves within the postmodern literature supported by statements from the critics John N. Duvall, (2008) and Peter Knight (2008) who hold this view. However, Falling Man is not considered one of his best novels as it fails to meet his audience's satisfaction. Another fact about Falling Man is that it depicts the 9/11 event by intermingling facts driven by pictures and news of the event and by the prediction made in his previous works. It is one of the novels about $9 / 11$ that reconsider the oppositions between us vs. them, personal vs. political, private vs. public, the oppressor vs. the victim (Gray, 2011).

The narrative of Falling Man revolves around Keith who survives the South Tower during the bombing. When the North Tower collapses Keith escapes to Lower Manhattan. Then, Keith's life with his family in the aftermath continues three years later. The novel shows flashbacks to the time before the attacks where a group of terrorist cell plans their attacks. The novel ends with the suicide bomber inside the towers to explode them. The whole novel, from the beginning to the end makes a full circle for the incident pre, during, and post the attacks. Falling Man follows the mentality of the extremists themselves shedding light on their extreme viewpoint about the world. The novel presents characters such as Hammad and Mohammed Atta to reveal the way an extremist perceives everything around and the beliefs that identify him as an extremist. The novel provides its readers with two different worlds and societies, the group of Muslim fundamentalists and the American culture. All this is mixed with the novelist's comments. The novel represents the extremists part mainly through the character of Hammad through focusing on Hammad's confusion who is baffled between keeping the necessary human desires or adopting the false society of al-Qaeda by struggling such desires (Rowe, 2011).

\subsubsection{Critical stylistics}

Critical stylistic analysis is an approach to language study by Jeffries who merges stylistic analysis with critical discourse analysis. It has emerged as a reaction to the critical discourse analysis since it does not provide a satisfactory set of analytical tools as Fairclough (1989) accepts this fact by stating:

The present chapter is written at an introductory level for people who do not have extensive backgrounds in language study...The set of textual features included is highly selective, containing only those which tend to be most significant for critical analysis. (p.110)

Although Fowler presents the following tools (transitivity, some syntactic transformations of the clause, lexical structure, modality, and speech acts), Jeffries views that they do not give thorough coverage of linguistic features. Critical stylistics acknowledges its debt to critical discourse analysis. Hence, essential attempts of critical stylistics is to provide the analytical tools for examining how a text affects the ideology of its recipients. Text is not a mere grammatical unit;

Arab World English Journal for Translation \& Literary Studies 
instead it is more suitable to consider it as a semantic unit because it has form and meaning (Abdul Zahra \& Abbas, 2004). According to Jeffries (2010), all kinds of texts, whether political texts, poems, novels, newspapers have meaning and conceal a specific ideology.

Jeffries (2010) sets the objectives of critical stylistics which are similar to those of Simpson (1993). Jeffries is concerned with the stylistic choices and textual analysis which are made by a text producer whether intentionally or not. Such a text conveys particular ideologies that influence the text recipient. The aim of using critical stylistics tools is to make the text recipient conscious of these ideologies, whether they alter their viewpoints or not.

Furthermore, Jefferies (2015) makes use of Halliday's metafunctions by reproducing them. She renames these metafunctions (textual, interpersonal, and ideational). Thus, the textual metafunction parallels the linguistic meaning in Jefferies terms in which it includes the linguistic structure and meaning to include Phonetics, Phonology, Morphology, Syntax, and Semantics. The ideational meta-function is called by Jefferies, the "textual meaning," and it represents the cotextual effect in which the linguistic system creates certain structures. Also, it manifests the way they work to deliver certain ideologies. It answers the question of what text is doing in creating ideational 'world.' This textual meaning is at the core of critical stylistics as it is in the mid-way between language structures and language system and the contextual influences and individual responses of the situation. Finally, the interpersonal meaning which comprises pragmatics is wholly contextual. It is related to the question of what language is doing to/with the people in the situation.

According to Jeffries (2010), how language embodies the world is solely related to the way the author depicts what he/she views in a linguistic form. For her, all kinds of texts have ideological basis. She adds that it is not impossible to spell out the ideologies that a text constructs an acceptance or a disproof by its readers. She gives an example of the far-right political group like the British National Party and how their ideologies are evidenced in their propaganda. In addition to how such ideologies are clear for the supporters and opponents of such a text; without indicating that the two groups will be affected equally by the same text.

To sum up, critical stylistics is defined by Jeffries (2010) as a method of finding the ideology in any text, whether or not you agree with it.

\subsection{Methodology}

\subsubsection{The adopted model}

The present study is a critical stylistic one, and it relies on adopting the textual conceptual model of Jeffries (2010). This model consists of ten tools (naming and describing, representing actions/events/states, equating and contrasting, exemplifying and enumerating, prioritizing, implying and assuming, negating, hypothesizing, presenting other's speech and thoughts, and representing time, space and society). These are known as critical stylistic tools. Nevertheless, the present study will limit itself to seven only (naming and describing, representing actions, states and events, equating and contrasting, implying and assuming, negating, hypothesizing, and space,

Arab World English Journal for Translation \& Literary Studies 
time and society representation). The reason behind choosing seven tools only serves the purpose of revealing the concept of extremism directly as they offer a thorough explanation of the extremist's ideology in the selected extracts. The following sections will review the selected critical stylistic tools in detail.

\subsubsection{Textual conceptual model}

Textual conceptual functions model is the model set by Jeffries for her critical stylistic approach. The functions in this model represent the level of meaning that lies between language structure and language in context. They are part of the ideational function of language as they create worldviews.

At the core of critical stylistics lies the notion that there is a level of meaning which sits somewhere between the systematic meaning and the contextual meaning of language. In other words, they represents Saussure's 'langue' and 'parole.' Within the level of contextual meaning, the text (or utterance) will employ language resources to show a certain view of the real-world or the fictional world in literature. It is this level of meaning that concerns the analysts to discover what the texts are doing in presenting the world. Here comes the role of textual conceptual functions that help to uncover the various types of meanings created by a certain type of texts (Jeffries, 2014).

It is a mixture of textual features and ideational function. It comprises a prototypical form which always transmits the conceptual effect, and occasionally peripheral form which also transmits the conceptual effect. For example, negation can take the prototypical form characterized by 'no' and 'not'; morphological negators like 'un', 'dis' etc.; grammatical items with semantic content 'never', 'nowhere' or it takes the peripheral lexical items like 'lack', 'fail' etc. (Jeffries, 2014).

The whole idea behind the textual conceptual functions is that they attempt to seize whatever the text is doing conceptually in presenting the world (or the fictional world in the case of literature).

To sum up, Jeffries states that textual conceptual functions with its tools might not be a comprehensive, but they present a coherent model. Such a model is not restricted to these tools; tools of this kind can be added with keeping the basic model.

\subsubsection{Critical stylistic tools}

\subsection{Naming}

It is believed that the text is used to name the world. For example, a person may have the name Janie Jackson and might be called 'the beautiful girl,' or 'the worker in the factory' or any other way of naming. Before going deep in the discussion of naming, a note for the main parts of the sentence should be made, which are the verb phrase and noun phrase. For verb phrases, they stand for processes, actions, or states. While for the noun phrases, they stand for entities. Such noun phrases function as either the grammatical subject or object of a verb. Thus, its role in a sentence is an actor when it is the subject and a goal when it is the object. However, noun phrases are 
AWEJ for Translation \& Literary Studies Volume, 3 Number 3. August 2019

employed ideologically in a text to 'package up' ideas and information which are not about the entities but actions, processes, or events.

The process of naming includes the following practices:

1-The choice of a noun

The choice of a noun refers to the selection of a noun to exemplify a referent. The selection of a certain noun to refer to something rather than another. Such a selection denotes or enhances a certain ideology, for instance, the choice between 'boss' and 'manager.'

2-Noun modification

Naming involves not only the choice of nouns, but it also involves the use of nouns modifiers. These nouns modifiers are additional information that can be included to modify the noun such as 'The honest child.' Such a process of modification and the use of particular modifiers carries particular ideological potentials.

\section{3-Nominalization}

The last technique of naming is nominalization. The use of nominalization is not newly presented in Jeffries approach, it is used before by the critical discourse analysis. This technique involves the transformation of a verb to a noun. For example, a verb such as 'add' becomes 'addition' or the verb defend becomes 'defense' etc.

\subsection{Representing actions/events/states}

It is one of the tools of analysis that is presented by Jeffries in her critical stylistic approach. It refers to transitivity choices. In other words, it refers to the choice of a verb. It criticizes the previous models of transitivity such as the Latin-based model of transitivity. The focus of that model only on distinguishing between the transitive verb (that requires an object) and intransitive verb (that does not require an object). It does not label the ditransitive verbs where they require more than one object, or the verbs which require an adverb of place, or verbs such as "drop" where it is intransitive with an inanimate subject and transitive with animate. Hence, such a model discards the meaningful aspects behind verb choice in favor of structural aspects. However, Jeffries finds that Halliday's model of transitivity that is adopted by the critical discourse analysis is concerned more with the meanings behind verb choices. According to this model, the choice of verbs underlies a certain view that is essential to each clause, and it plays a role in affecting the other parts of the clause. According to Simpson(1993), transitivity is part of the ideational function. This function refers to the way that meaning is exemplified in the clause. It displays the way that language users encode their mental picture of reality and the way they exemplify their experience of the world around them.

So far, Jeffries (2010) adopts Simpson's model of transitivity (1993). In this model, the lexical verbs are distributed across four main categories as far as the processes they indicate are concerned :

Arab World English Journal for Translation \& Literary Studies 
1-Material action process which consists of three subcategories as follows: intention (it comprises conscious being i.e., The man throws the book.), supervention (it comprises unintentional actions i.e., The man fell on his knee.), and event(it comprises the use of inanimate actor i.e., The car damaged.);

2-Verbalization process which describes actions that use human language and include verbs such as 'told,' 'reported,' etc.;

3-Mental-cognition process which represents the processes that the human beings experience. It includes three subcategories as follows, mental cognition (think, know, realize, etc.), mental reaction (feel, like, hate, etc.), and mental perception (see, hear, taste, etc.); and

4-Relational process, which is the final category of verb processes. It refers to the stable relationships between carriers and attributes. It includes the intensive relational process (verbs to be), possessive relational process (have, has, etc.), and circumstantial relational process (verbs of movement, verbs to be).

\subsection{Equating and contrasting}

This tool refers to the use of similarity construction as it is represented by equating and opposition construction which is represented by contrasting. Both of equating and contrasting have certain syntactic triggers or linguistic realizations that identify them. However, in each case these triggers are not definite ones and new triggers can be added.

According to Jeffries (2010), equivalence or equating triggers are mainly included in the following list:

1-Intensive relational equivalence $\mathrm{x}$ is $\mathrm{y}, \mathrm{x}$ seems $\mathrm{y}, \mathrm{x}$ becomes $\mathrm{y}, \mathrm{x}$ appears $\mathrm{y}$

2-Appositional equivalences $\mathrm{x}, \mathrm{y}, \mathrm{z}$

3-Metaphorical equivalences $\mathrm{x}$ is $\mathrm{y}, \mathrm{x}$ is like $\mathrm{y}$

While for contrasting or opposition, Jones (2002), Davies (2008) and Jeffries (2007) set possible linguistic realizations as the following list shows :

1-Negated opposition $\mathrm{x}$ not $\mathrm{y}$

2-Transitional opposition turn $\mathrm{x}$ into $\mathrm{y}$

3-Comparative oppositions more $\mathrm{x}$ than $\mathrm{y}$

4-Replacive opposition $\mathrm{x}$ instead of $\mathrm{y}$

5-Concessive opposition despite $\mathrm{x}, \mathrm{y}$

6-Explicit oppositions $\mathrm{x}$ by contrast with $\mathrm{y}$

7-Parallelism He liked $\mathrm{x}$, she liked $\mathrm{y}$, your house is $\mathrm{x}$, mine is $\mathrm{y}$

8-Contrastives $\mathrm{x}$, but $\mathrm{y}$

\subsection{Implying and Assuming}

Implying and assuming refers to the employment of implicature and presupposition. Starting with implying, the model of implicatures is drawn from Grice's $(1975,1978)$ work (as cited in Jeffries, 2010). This model is based on the notion of the cooperative principle and Grice's four maxims 
(maxim of quality saying the truth, quantity saying as much as it is required, relation be relative and manner avoid obscurity). Any flouting in one or more of these maxims will lead to implicature. The implying process attempts at finding these implicatures to detect the ideological potentials behind any implied meaning.

As for assuming, it is parallel to presupposition which denotes "the assumptions that are built into the text" (Jeffries, 2010, p.94). A principle issue in presupposition is the invariable proposition in the cases of negation and interrogation (Abbas, 2005). As far as Jeffries is concerned, she limits presupposition to two main types as follows:

1)Existential presupposition: it is the type of presupposition that is identified by the use of definite noun phrases. It is introduced by the use of the determiner 'the' or demonstratives 'this,' 'that,' 'those,' 'these,' or introduced by the use of possessive forms (my, our, their, his, her, its, your).

2)Logical presupposition: it is the type of presupposition that is less easy to identify than the existential presupposition. Logical presupposition has a set of triggers as the following list:

-Changing the state of the verb which presupposes the earlier state of affairs; i.e., She stopped smoking.

-Using factive verbs like realize, know, understand, regret, discover, with the clausal complement usually starting with 'that' and this clausal complement carries the presupposition; i.e., He regrets that the car has damaged.

-Using a cleft sentence which presupposes the post-modifying relative clause i.e., It was Janet that damaged your car.

-Using iterative words such as again, yet, any more, or verbs like a rewrite, revisit, etc. These words and verbs presuppose a process which takes place earlier or later i.e., They will not change their office anymore which presupposes that they changed their office before.

-Using comparative structures which presupposes the comparison basis of two entities. For example, 'Linda is as innovative as Susan' which presupposes that Susan is innovative.

\subsection{Negating}

It is the tool by which text producers create a view of a world that does not exist; in other words, create an alternative reality which is considered to be unreal. Nevertheless, the text recipient will conceptualize this hypothetical worldview as it has a kind of persuasive power.

It is important to note that the process of negation is realized by a set of triggers, as shown in the list below:

1-Syntactically by adding the negative particle to the verb phrase either to the auxiliary or the dummy auxiliary verb. If there is not an auxiliary, the negative particle can be added to the dummy auxiliary (do;)

2-Another way of negating is through the use of pronouns such as 'nobody,' 'no one,' 'nothing,' 'none' etc. or by using the adjectival no to modify the noun such as 'nobody';

3-Lexically through the semantics of certain words having negative connotations in the openended list that consists of nouns (lack, absence), verbs (exclude, omit, reject), adjectives (absent, scarce), adverbs (rarely, seldom); and 
4-Morphologically like the following negated adjectives irrational, unprofessional, or the negative verbs like 'disconnect,' 'disrespect.'

\subsection{Hypothesizing}

This tool refers to the process by which the text producers do not always providing the view of the world as it is. On the contrary, they sometimes provide their own view of the world by creating a hypothetical reality. This falls within the system of modality, which uses a critical approaches to language, and it is one of the major functions in Halliday's functional system (1985). For this textual tool, Jeffries adopts Simpson's model of modality (1993) which comprises the use of modal auxiliary verbs such as 'will,' 'would,' 'shall,' 'should,' 'can,' 'could,' 'may,' 'might,' 'must,' 'ought,' 'dare,' and 'need.' Each of these modal auxiliaries has a modal meaning or several meanings. The first modal meaning is epistemic (likelihood), which indicates the speaker's doubt or certainty. The second modal meaning includes either the expression of obligation known as a deontic modality or the expression of desirability known as a boulomaic modality.

However, there are other forms of modality which includes the use of lexical verbs such as 'think,' 'suppose'/ Modal adverbs such as 'probably,' 'maybe,' 'definitely'/ Modal adjectives such as 'probable,' 'possible,' 'definite,' 'sure,' 'certain '/Conditional structures such as 'if,' 'then.'

Back to Simpson's model, in his model, he introduces a combination of person, modality, and semantic aspects of a text. For a person, it refers to first-person narration labeled as category A and third-person narration labeled as category B. It consists of the narration mode where the viewpoint is expressed without the consciousness of any participant in the narrative, and the reflector mode where the viewpoint is expressed with the consciousness of the participants. The categories and subcategory have three shades of modality:

1-Positive deontic and boulomaic;

2-Negative epistemic and perception modality; and

3-Neutral complete absence of narrational modality.

\subsection{Space, time and social presentation}

This tool of analysis deals with how the text producers construct the world in space, time and society dimensions, and these are known as "text world theory". To access such dimensions, Jeffries relies on the model of deixis. The importance of deixis lies in the information that it yields a particular interpretation of a particular utterance in a particular contexts of a situation, on the contrary, the lack of this information yields misinterpretation (Abdul-Majeed, 2016). The potential behind deictic expressions is to highlight a certain time, place, and social circumstance. The speaker of a certain text in a certain time and place is presumed to be at the deictic center. The English language has the following main categories of deictic expressions:

1-Place deictic $\rightarrow$ which is expressed by the use of adverbs such as here and there; demonstrative such as this, that, those, and these; prepositional structures such as in front of, opposite to, etc.

2 -Time deictic $\rightarrow$ which is expressed by adverbs now and then, verb tenses, demonstrative, adverbials later, earlier, etc.

Arab World English Journal for Translation \& Literary Studies 
AWEJ for Translation \& Literary Studies Volume, 3 Number 3. August 2019

Critical Stylistic analysis of the Concept of Extremism

Ahmed \& Abbas

3-Personal deictic $\rightarrow$ which is expressed by personal pronouns first person, second person, and third persons; and

4-Social deictic $\rightarrow$ which includes Mr., Dr., etc.

\subsubsection{Methodological procedures}

The present study will make use of the previously mentioned critical stylistic tools to detect the language and the underlying meaning of extremism in Falling Man. The analysis of data will be based on five extracts from Falling Man. To achieve a comprehensible procedure of analysis the researchers organize the analysis as the following list illustrates :

1. Selecting certain utterances from the extracts that manipulate a certain ideology of extremism;

2. Figuring the linguistic meaning: this part gives an account on detecting the selected text linguistically, and it is after the structure of each extract;

3. Uncovering the textual or ideational meaning: which is after the way that each extract exploits the linguistic choices to deliver a particular ideology about extremism; and

4. For a clarification purpose, the researcher attaches a table beneath each section of the analysis of the five extracts. The tables will show each sentence, and the tools used in uncovering the extremist ideology with its target. It is important to note that the target represents the linguistic realization identified within each tool of analysis. 5 .

\subsubsection{Data analysis}

The researchers have selected five extracts which are speculations of the character of Hammad in Falling Man by DeLillo (2007) to examine extremism using Jeffries (2010) model of critical stylistics.

\section{Extract 1}

Hammad sat crouched, eating and listening(1). The talk was fire and light, the emotion contagious(2). They were in this country to pursue technical education but in these rooms they spoke about the struggle(3). Everything here was twisted, hypocrite, the west corrupt of mind and body, determined to shiver Islam down to bread crumbs for birds(4). (P.79)

\section{Linguistic meaning}

This extract describes the extremists as they are condemning the west. At the beginning of the fourth utterance (Everything here was ... hypocrite) the subject 'Everything' is described as being 'twisted' and 'hypocrite.' While the noun phrase 'the west' is modified by 'corrupt of mind and body.' Furthermore, the extract constructs opposition through the noun choice of 'the west' and 'Islam.'

\section{Textual meaning}

The use of the place deictic 'here' at the beginning is a place representation, and it denotes Western society. The subject 'Everything here' is equated with 'twisted' and 'hypocrite' to form a metaphorical equivalence. Thus, everything in this society is twisted and hypocrite. Words such 
as a 'hypocrite' and 'twisted' are principally used to refer to a human agent; however, it is used as a metaphor since the subject is inanimate (everything). Thus, the process of equating reveals the extremist's view about Western society as it holds the belief that everything in such a society is 'twisted' and 'hypocrite.' This is a generalization, as it refers to everything. In this case the extremists leave nothing as they perceives everything related to Western society is 'twisted' and 'hypocrite.' This is an extreme way of thinking to condemn the whole society with such a description.

Moreover, in the second part of the utterance, the naming process is apparent. The noun phrase 'the west' is one of the labels that is always used by the fundamentalists to refer to Western society. This choice of the noun refers to 'Everything here' mentioned at the beginning, which means that the west refers to the Western society, which is 'twisted' and 'hypocrite.' The utterance continues with the west corrupt of mind and body which is a metaphorical equivalence. Since 'the west' is non-human to have a mind and a body to be corrupted, thus, this is a metaphor refers to the Western society. Ideologically, the noun phrase and the metaphorical equivalence denote the extremist's view of 'the west' as it is corrupted in their minds and souls. Such view considers them to be corrupted from the inside (their thinking) and outside (their appearance). This is a pretext for those extremists to fight and bomb the western people.

The naming process makes use of the west vs. Islam to construct a difference between the two. The equating process deems the west to be immoral through the metaphors (twisted, hypocrite, corrupt of mind, and body). Conceptually, extremism is built in the structure through the naming choices as they set the difference between the West and Islam, and equating strategies through which they make a judgment about the west immorality and corruption. All the above tools are summarized in table (1) below:

Table 1. Tools and targets in the first extract

\begin{tabular}{|l|l|l|}
\hline Utterance & Tool & Target \\
\hline $\begin{array}{l}\text { Everything here was } \\
\text { twisted, hypocrite, } \\
\text { the west corruption } \\
\text { of mind and body, } \\
\text { determined to shiver } \\
\begin{array}{l}\text { Islam down to bread } \\
\text { crumbs for birds }\end{array}\end{array}$ & Space representation & Place deictic 'here' \\
& Equating & $\begin{array}{l}\text { Choice of noun } \\
\text { 'Islam'; 'the west' }\end{array}$ \\
\hline
\end{tabular}

\section{Extract 2}

He was very genius, others said, and he told them that a man can stay forever in a room, doing blueprints, eating and sleeping, even praying, even plotting, but at a certain point he has to get out(1). Even if the room is a place of prayer, he can't stay there all his life(2). Islam is the world 
AWEJ for Translation \& Literary Studies Volume, 3 Number 3. August 2019

Critical Stylistic analysis of the Concept of Extremism

Ahmed \& Abbas

outside the prayer room as well as the Surah in the Koran(3). Islam is the struggle against the enemy, near enemy and far, Jews first, for all things unjust and hateful, and then the Americans(4). (P.79-80)

\section{Linguistic meaning}

This extract displays a description of Amir, the leader of the terrorist group. The extract reveals Amir's beliefs through the use of the indirect speech. The first utterance comprises the modality choices of 'can ' and 'has to' beside the transitivity choices (stay, and get out). Furthermore, it introduces a contrast using 'but.' However, the second utterance employs negation to the modal verb 'can.' While, the third utterance starts with the subject 'Islam' and the intensive relational verb 'is' with the adverbial phrase 'the world outside the prayer room' as its complement. Also, the subject complement 'The world' is modified using of place deictic 'outside.' Finally, the fourth utterance also has Islam as its subject and the intensive relational verb 'is' as its main verb, the struggle against the enemy as its complement which is modified by the apposition 'near enemy and far.'

\section{Textual meaning}

The above extract employs a set of critical stylistic tools such as modality, transitivity, contrasting, equating, and assuming. The subordinate clause 'that a man can stay forever in a room' in the first utterance starts with the creation of the hypothetical world. It is introduced by the modal verb 'can' and the rest of the clause in which a man stays forever in a room. The hypothesizing process, which is represented by the epistemic modality through the verb 'can' foreshadows a doubt about staying in a shell-like room. This is proved by the contrast, 'but at a certain point he has to get out.' The contrast shows the contradictions and complexities within the extremist's mind. By setting the contrast with the deontic modality in 'but at a certain point he has to get out,' a man is obliged to get out for a certain purpose. This might imply that he is getting out to kill or bomb. The final clause indicates that they are waiting something for getting out, they are getting out for a particular purpose to be fulfilled. The next utterance consists of the main clause 'he can't stay there all his life' and a subordinate clause introduced by 'even if the room is a place of prayer.' By placing the negated hypothetical clause 'he can't stay there all his life' at a higher-level structure, the speaker is prioritizing the idea of not staying over praying. Thus, the reader of the text will become skeptical about the speaker's motifs behind getting out and will think of different scenarios resulting after getting out. Also, the reader will construct the image that this group of people when they are staying at a room their life is restricted to 'eating,' 'sleeping,' 'praying' and 'plotting' and nothing else. It is as if they exclude every activity in life other than the mentioned which by itself an extreme way of living. Thus, those extremists spend their life either isolated in a room doing nothing except eating, sleeping, praying, and plotting or getting out when the time comes for a particular purpose.

The next utterance 'Islam is the world outside the prayer room' is equated with the utterance that follows 'Islam is the struggle against the enemy through the parallel structure. Both utterances contain the carrier 'Islam,' and the intensive relational verb 'is' but with different attributes in each sentence. The implication behind such equating is that the world outside the prayer room in the

Arab World English Journal for Translation \& Literary Studies 
first utterance is the struggle in the second utterance. It implies that for those extremists, the world outside the borders of the prayer room is only a struggle for him since the noun 'Islam' does not refer to Islam as the holy religion. Instead, it relates to their interpretation of Islam as a struggle. Furthermore, Amir uses at the beginning 'a man can stay.... he has to get out'; then he starts to use Islam to make his addressee identify himself/ herself with Islam. This will make his view stronger when it is being carried out by the label of Islam. 'The struggle against the enemy' by its own is an existential presupposition with the definite noun 'The struggle.' It presupposes that there is a struggle, and there is an enemy for the speaker. This raises the image of the struggle between Islam and the enemy. This enemy represents the West in general and the American and Jews in particular. Besides, the noun phrase 'the enemy' is identified by the contrast 'near' and 'far' with further identification as Jews and Americans who are named as enemy. From this whole paragraph, it becomes apparent that the motive of the speaker behind getting out is the struggle against the enemy. Actually, this is what constitutes the ideology of extremism, which is based on having enemies that must be struggled.

In this extract, the extreme ideology is presented a step by a step from staying at a room then getting out to struggle against Americans and Jews as for him. All in all, the above extract incorporates the use of transitivity choices, equating, assuming, and hypothesizing. The transitivity choices here identify through the dynamic material action intentional verbs the main activities of the extremists in life whether staying enclose in a room isolated from the outside world or getting out for a particular purpose. Then, they identify Islam with the use of the stative intensive relational 'is' as a religion of struggle. However, the equating process finds its own way in the last two utterances to mirror the world as a struggle for Islam. While the hypothesizing process shows the alternative realities for those extremists either to stay enclosed in a room or to get out for a certain purpose. As far as the assumption process, it hints on the extremists' claims that they are living in a struggle. The tools and targets of the second extract are summarized in table (2):

Table 2. Tools and targets in the second extract

\begin{tabular}{|l|l|l|}
\hline Utterance & Tool & Target \\
\hline $\begin{array}{l}\text { a man can stay } \\
\text { forever in a room, } \\
\text { doing blueprints, } \\
\text { eating and sleeping, } \\
\text { even praying, even } \\
\text { plotting, but at a } \\
\text { certain } \text { point he has } \\
\text { to get } \text { out }\end{array}$ & Hypothesizing & Epistemic modality \\
\hline $\begin{array}{l}\text { Even if the room is } \\
\text { a place of prayer, } \\
\text { he can't stay there } \\
\text { all his life. }\end{array}$ & Hypothesizing & Deontic modality \\
\hline
\end{tabular}

Arab World English Journal for Translation \& Literary Studies 
AWEJ for Translation \& Literary Studies Volume, 3 Number 3. August 2019

Critical Stylistic analysis of the Concept of Extremism

Ahmed \& Abbas

\begin{tabular}{|l|l|l|}
\hline $\begin{array}{l}\text { Islam is the world } \\
\text { outside the prayer } \\
\text { room as well as the } \\
\text { Surah in the Koran }\end{array}$ & Transitivity & $\begin{array}{l}\text { Intensive relational } \\
\text { verb }\end{array}$ \\
\hline $\begin{array}{l}\text { Islam is the } \\
\text { struggle against the } \\
\text { enemy, } \\
\text { near enemy and } \\
\text { far, Jews first, for } \\
\text { all things unjust and } \\
\text { hateful, and then the } \\
\text { Americans }\end{array}$ & Transitivity & Equating \\
\hline
\end{tabular}

\section{Extract 3}

Hammad in a certain way thought this was unfair(1). But the closer he examined himself, the truer the words (2). He had to fight against the need to be normal(3). He had to struggle against himself first, and then against the injustice that haunted their lives(4). (P.83)

\section{Linguistic meaning}

The above extract exposes Hammad's inner thoughts and psychological struggles. Starting with the third utterance, it employs the subject 'he' followed by the deontic modality through the use of modal auxiliary 'had to' plus the material action verb 'fight' and the preposition ' against.' The rest of the utterance represents an existential presupposition 'the need to be normal.' The fourth utterance also employs deontic modality through 'had to' plus the verb 'struggle' with a two-part list that identifies the things for which he had to struggle. These things are represented by him, and the morphological negation in 'the injustice' which is modified by the relative clause 'that hunted their lives.'

\section{Textual meaning}

In this extract, the third utterance has an existential presupposition 'the need to be normal.' It presupposes that the need for normality exists inside Hammad. However, by using the deontic modality (obligation) he "had to" fight this need, he creates an alternative world in which he bares himself from this need of normality to be abnormal. This is an extremist ideology because being abnormal means being an extremist as those extremists fight everything normal. The transitivity choice of the material action intentional verb 'fight' proves this extremist world view of fighting anything normal. He continues creating an alternative world again by using the deontic modality 'he had to struggle' two things 'himself' and 'the injustice' that haunted their lives. Moreover, he uses the material action intentional verb 'struggle' with 'he' as an actor and himself and the injustice as the goal of this struggle. In other words, Hammad's struggle is inside that is represented by himself and the outside that is represented by the injustice of the Western society. Not only this; but also this injustice is an existential presupposition. It presupposes that the speaker and his group are living in injustice which haunts their life. He uses 'their' to generalize the idea of the injustice

Arab World English Journal for Translation \& Literary Studies 
that haunts them as Muslims. The reader of this utterance will start to think of what type of injustice the speaker means.

Overall, the above extract makes use of assuming, hypothesizing, transitivity choices, and negation to carry the ideational meaning of the extremist's view of fighting against the normality, and the assumed injustice. For assuming, the existential presupposition sheds light on the fact that Hammad confesses with his need to be normal that exists within himself. Nevertheless, the hypothesizing process of using deontic modality (had to) with the transitivity choices of verbs 'fight/struggle,' yields an obligation to fight this need. Moreover, he uses this deontic modality to oblige himself to struggle with the injustice that haunts their life. The negation process of adding the prefix 'in' to justice shows that Hammad and his group live in injustice. In other words, for him they are not treated equally because of the injustice of the Western society. Consequently, Hammad attempts at creating a worldview in which he and his group can live in 'justice,' in that case he will not struggle anything. Hence, he has to struggle this injustice to achieve justice. It is important to note that Hammad tries to convince himself that he and his group are living in injustice to justify his struggle. This is part of extremism in which the extremists attempt at convincing themselves and finding justifications for their activities. All this happens within inside their minds, in other words, they view the world as they like. Finally, this extract involves the struggle within one's mind to depart against normality and adopt the extremist's views. All the above points are summarized in the table below:

Table 3. Tools and targets in the third extract

\begin{tabular}{|c|c|c|}
\hline Utterance & Tool & Target \\
\hline $\begin{array}{l}\text { He had to fight } \\
\text { against the need to } \\
\text { be normal }\end{array}$ & $\begin{array}{l}\text { Hypothesizing } \\
\text { Transitivity } \\
\text { Assuming }\end{array}$ & $\begin{array}{l}\text { Deontic modality } \\
\text { Material action } \\
\text { intentional verb } \\
\text { Existential } \\
\text { presupposition }\end{array}$ \\
\hline $\begin{array}{l}\text { He had to struggle } \\
\text { against himself first, } \\
\text { and then against the } \\
\text { injustice that } \\
\text { haunted their lives }\end{array}$ & $\begin{array}{l}\text { Transitivity } \\
\text { Hypothesizing } \\
\text { Negation }\end{array}$ & $\begin{array}{l}\text { Material action } \\
\text { intention verb } \\
\text { Deontic modality } \\
\begin{array}{l}\text { Morphological } \\
\text { negation }\end{array}\end{array}$ \\
\hline
\end{tabular}

Arab World English Journal for Translation \& Literary Studies 
AWEJ for Translation \& Literary Studies Volume, 3 Number 3. August 2019

Critical Stylistic analysis of the Concept of Extremism

Ahmed \& Abbas

\section{Extract 4}

They read the sword verses of Koran(1). They were strong willed, determined to become one mind(2). Shed everything but the man you are with(3). Become each other's running blood(4). (P.83)

\section{Linguistic meaning}

The present extract displays a description of the extremists. The first utterance comprises the use of the subject 'they' referring to the group of extremists and the verb 'read' with the object introduced by the phrase 'the sword verses of Koran.' The third utterance proceeds with the verb 'shed' and the object 'everything' with using the contrastive 'but' which excludes only their group from this process of shedding. The extract closes with the intensive relational 'become,' and this time, they will be each one's running blood.

\section{Textual meaning}

In the first utterance of this extract, the choice of the noun phrase 'the sword verses' underlies the fact that as from the holy Koran the extremists made up their mind to read only the verses related to sword which hints on their motifs for fighting. Also, the role of the noun phrase as an object puts it in the position of a goal for the material action intentional verb 'read.' In other words, reading only' the sword verses' hints on their willingness to fight. Such a choice of the noun phrase 'the sword verses of Koran' foreshadows the writer's viewpoint in linking Islam, the extremist ideology, and violence together, just to mirror Islam as an extreme religion. Another ideological potential that can be recovered from this extract is the transitivity choice of the material action intentional verb 'shed.' It suggests their attempt to get rid of everything except the members of their group. By making such an implication, they go so far in their extreme world by excluding everything and everyone outside their group.

The extract contains transitivity choices and a naming process to reinforce the extremist's violent attitudes. The naming process through the noun choice of 'sword verses' holds the idea that those extremists interpret and choose from Koran what they like to meet their willingness to fight. Furthermore, the transitivity process through the material action intentional verb 'shed' with 'everything' as the affected foreshadows their determination for violence. Also, the contrasting process through using 'but,' and the rest of the utterance, sets a contrast between insiders and outsiders. The insiders represents the extremists group, and the outsiders represents the Western society. As a result, the transitivity and contrasting processes emphasize the idea they are now ready to kill and fight everything outside their extremist world. The idea of in-group and out-group becomes apparent in this extract as it is evident in 'shed everything, but the one you are with.' By this, the extremist's ideology reaches its peak.

Arab World English Journal for Translation \& Literary Studies 
AWEJ for Translation \& Literary Studies Volume, 3 Number 3. August 2019

Critical Stylistic analysis of the Concept of Extremism

Ahmed \& Abbas

Table 4. Tools and targets in the fourth extract

\begin{tabular}{|c|c|c|}
\hline Utterance & Tool & Target \\
\hline $\begin{array}{l}\text { They read the sword } \\
\text { verses of Koran }\end{array}$ & $\begin{array}{l}\text { Transitivity } \\
\text { Naming }\end{array}$ & $\begin{array}{l}\text { Material action } \\
\text { intentional verb } \\
\text { Choice of noun }\end{array}$ \\
\hline $\begin{array}{l}\text { Shed everything but } \\
\text { the man you are } \\
\text { with }\end{array}$ & $\begin{array}{l}\text { Transitivity } \\
\text { Contrasting }\end{array}$ & $\begin{array}{l}\text { Material action } \\
\text { intentional verb } \\
\text { The conjunction } \\
\text { 'but' }\end{array}$ \\
\hline
\end{tabular}

\section{Extract 5}

The beard would look better if he trimmed it(1). But there were rules now and he was determined to follow them(2). His life had structure(3). Things were clearly defined(4). He was becoming one of them now, learning to look like them and think like them(5). This was inseparable from jihad(6). He prayed with them to be with them(7). They were becoming total brothers(8). (p.83)

\section{Linguistic meaning}

The last extract is a description of Hammad's life within the group of extremists. It starts with a hypothesizing process in "The beard would look better if he trimmed it". Then, it continues with a contrast in the second utterance. As for the fifth utterance, it comprises the use of transitivity choice of the intensive relational verb 'becoming' and the time representation through the adverb 'now.' The sixth utterance employs the critical stylistic choices of the morphological negation 'inseparable,' and the noun choice 'jihad.' The utterance before the last makes use of the transitivity choice of the verb 'prayed' with the subject 'He' referring to Hammad and the prepositional phrase 'with them to be with them' as an object. Finally, the extract ends with the transitivity choice of the verb 'becoming.'

\section{Textual meaning}

The last extract includes a set of critical stylistic tools such as presupposition, hypothesizing, transitivity, contrasting, and equating. At the beginning of the extract, the hypothesizing process appears in the first utterance through the epistemic modality 'would' and 'if.' By doing so, the speaker creates an alternative world of trimming his beard to look better. The choice of epistemic modality through 'would' and 'if' shows that he is uncertain of whether keeping this beard or not. However, the second utterance sets a contrast to that alternative reality as it starts with the contrast 'but' in 'But there are rules now' plus the use of time representation 'now' suggests that his group puts rules, one of them is to have a beard. Thus, the first and second utterances suggest that if Hammad does not belong to the group, he will trim his beard to look better. The focus on the outside look is one of the indications of extremism as they attempt to have a unified look by growing beards. For Hammad, the first step to be an extremist is to keep his beard just like the other extremists even if he does not like the beard. Moving to the fifth utterance, it comprises the 
use of transitivity choice of the intensive relational verb 'becoming' with 'he' as the carrier and 'one of them' as the attribute. The transitivity choice and the time representation here show the turning process that becomes clear through the time deictic 'now' which is a time representation indicating that the relation between the carrier 'he' and the attribute' one of them' is a new one. The rest of the utterance continues by identifying how he becomes one of them by learning to look like them and think like them. So, the equating process through the parallel structure (look like them and think like them) proves that each one of those extremists looks and thinks like the other one in the group. In order to be one of them, Hammad has to learn to look and think like them. The next utterance proves this by using the morphological negation 'inseparable' in 'inseparable from jihad.' Thus, for those extremists unifying their looking and thinking is part of jihad. Through the negation, Hammad creates an alternative reality in which looking and thinking like his group can be separable from jihad. In such a case he would be free to think and look as he likes. He learns these beliefs because it is part of jihad to hold his group's beliefs. Furthermore, he adds that 'he prayed with them to be with them' using the material action intentional verb 'prayed' with the subject 'he' as an actor and the prepositional phrase' with them to be with them' as a goal. He confines the process and the aim of prayer to be part of the group. The last utterance makes use of the transitivity choice of the intensive relational verb 'becoming' with 'they' as a carrier and "total brothers" as an attribute to shed light on repeating the idea of the in-group. To sum up, this extract reinforces the idea of one group holding the ideology, the beliefs, thoughts, and the look of that group. The above-mentioned tools and targets are shown in table (5):

Table 5. Tools and targets in the fifth extract

\begin{tabular}{|l|l|l|}
\hline Utterance & Tool & Target \\
\hline $\begin{array}{l}\text { The beard would look } \\
\text { better if he trimmed it. }\end{array}$ & Hypothesizing & Epistemic modality \\
\hline $\begin{array}{l}\text { But there were rules } \\
\text { now and he was } \\
\text { determined to follow } \\
\text { them. }\end{array}$ & Contrasting & The conjunction 'but' \\
\hline $\begin{array}{l}\text { He was becoming one of } \\
\text { them now, learning to } \\
\text { look like them and think } \\
\text { like them. }\end{array}$ & Transitivity & The adverb 'now' \\
\hline $\begin{array}{l}\text { This was inseparable } \\
\text { from jihad. }\end{array}$ & Negation & Intensive relational verb \\
\hline $\begin{array}{l}\text { He prayed with them to } \\
\text { be with them. }\end{array}$ & Transitivity & Morphological negation \\
\hline $\begin{array}{l}\text { They were becoming } \\
\text { total brothers. }\end{array}$ & Transitivity & $\begin{array}{l}\text { Material action } \\
\text { intentional }\end{array}$ \\
\hline
\end{tabular}

Arab World English Journal for Translation \& Literary Studies

ISSN: 2550-1542 | www.awej-tls.org 
AWEJ for Translation \& Literary Studies Volume, 3 Number 3. August 2019

Critical Stylistic analysis of the Concept of Extremism

Ahmed \& Abbas

\subsubsection{Results and Findings}

The five extracts show that the critical stylistic tools work jointly to uncover the concept of extremism in the selected novel. The researchers finds out that modality, transitivity and assuming, transitivity and equating, transitivity and modality, are woven together in the text to create an inherently extreme world view. The selected critical stylistic tools vary in their existence in the selected extracts. Starting with the naming process, it appears twice in the first and fourth extracts only. It denotes a process of labeling. In the first extract, it sets a diverse line between two worlds represented by the West and Islam. In the fourth extract, it makes use of 'the sword verses of Quran' focusing on the words 'sword verses' to link Islam in one way or another to violent attitudes. The second tool, which is transitivity choices, it is implemented from the second extract to the last extract. Though it is used more in the last extract than in the second, third, and fourth extracts. It is repeated three times in the last extract while it is used only twice in the second, third, and fourth extracts. This attributes to the fact that the last extract demonstrates on how Hammad becomes one of the extremists by looking and thinking like them. It will make the reader of the novel assumes of what is the next thing that Hammad will do just like them. Contrasting and equating, both of them appear in the first, second, fourth, and fifth extracts. Assuming occurs twice in the second and third extracts. On the one hand, it constitutes the struggle between Islam and the West in the second extract. On the other hand, it shows Hammad's confession with his need to be normal in the third extract. As for negation is used twice in the third and the fifth extracts. It denotes Hammad's complaint of the life in the West in the third extract. While in the fifth extract is used to show how following the group of extremists for him is considered as something that cannot be separated from Islam. The hypothesizing process is used more in the second and the third extracts than in the last extract. It occurs twice in the second and the third extracts while it is used once in the fifth extract. Space and time representation appears in the first and the last extracts only with space representation in the first extract and time representation, which is used twice in the last. However, transitivity choices are highly structured in the text, particularly by adhering material action and intensive relational verbs. Throughout the five extracts, transitivity choices are built in the structure of the utterances and accompanied the other critical stylistic tools. For example, in the second extract, the transitivity choice of the intensive relational 'is' in the utterances 'Islam is the world...in Koran' and 'Islam is the struggle against the enemy...the Americans' constitutes an equating process through parallel structure to give the ideology that for those extremists the world outside the prayer room is the struggle against the enemy. Thus, the transitivity choices appears to be the most recurrent tool in four out of five extracts. The total number of transitivity choices is nine. Through using material action verbs contribute the main actions of the extremists in life represented by fighting, struggling, and shedding everything. While the intensive relational verbs construct certain facts that are considered to be traits of extremism. Then, modality comes in the second place as it appears five times in the analysis by focusing on epistemic and deontic modality. Nevertheless, the remaining critical stylistic tools ranging between three to two times in their occurrence throughout the five extracts. Following the five extracts on the ideological level, the extremist's ideology starts with constructing a diverse line between Islam and the west in the first extract. Furthermore, the second extract identifies the extremist's mentality and how it sets the idea of Islam's struggle. While the third extract follows the extreme ideology inside one of the extremists (Hammad) as he fights against the normality. The fourth extract sets

Arab World English Journal for Translation \& Literary Studies 
the ultimate aim of extremism of fighting and shedding everything except themselves and their group. While the last extract emphasizes the idea of in-group through becoming similar in their look and thoughts. The notion of the extremism in this novel attempts at associating Islam with fighting and struggling. This destroys the image of Islam and makes Islam something wrong. DeLillo in this novel presents an Orientalist perspective of Islam through presenting extremists Muslims who were growing beards and praying. Besides, he links the term Islam to struggle and fight. Such linkage retains the conflict between the east and the west as Islam has enemies who are the Western people in general and the American and Jews in particular.

\section{Conclusion}

The concept of extremism comprises a set of beliefs and notions which need to be accessed critically. As such, the current study finds its way by applying a critical stylistic approach. The work within this approach involves the analysis beyond the form-function relationship. Also, there is more than one tool of analysis that can work together to unlock the key to the ideology within each text. After analyzing each extract, it has become clear that more than one tool collaborates for uncovering extremism. This concept is revealed by the linguistic choices or tools that reflect the violence, struggle, abnormality, hatred, complex and contradictive nature of this concept. All these are conceded by implications, presuppositions, hypothesizing, representing space and time, representing actions, events, and states, equating and contrasting, negation, and naming processes. The present study proves this in the selected novel Falling Man that fictionalizes this concept backgrounded by DoLillo's view. The writer represents extremism as a synonym for Islam with picturing Islam as a religion of struggle and fight. To sum up, the researchers have found that the writer of Falling Man applies linguistic choices including nouns, verbs, conjunctions, modal auxiliaries, negation, deictics, and presuppositions to yield the concept of extremism that is based on struggling, fighting and hatred.

Acknowledgments: The researchers of the present study are indebted to the College of Education for Women, University of Baghdad, Al-Jadiriyya, for carrying out this study.

\section{About the Authors:}

Harir Aamer Ahmed is an M.A. candidate at the Department of English, College of Education for Women, University of Baghdad. Her field of study is linguistics and her specialization is concerned with Critical Stylistic Approach. Besides, she is interested in literature, critical studies and stylistics. ORCid ID : https://orcid.org/0000-0003-2531-2345

Nawal Fadhil Abbas got her PhD in English Language and Linguistics in 2014 from the school of Humanities, University of Sains Malaysia. Now she is an assistant professor teaching at the College of Education for Women, University of Baghdad. Her field of study is Semantics and Pragmatics. Other fields of interest include Critical Discourse Analysis, Critical Stylistics and Corpus Linguistics. ORCid ID: https://orcid.org/0000-0003-2608-6909 
AWEJ for Translation \& Literary Studies Volume, 3 Number 3. August 2019

Critical Stylistic analysis of the Concept of Extremism

Ahmed \& Abbas

\section{References:}

Abbas, N.F. (2005). Presupposition in Fitzgerald's "The Rough Crossing". Journal of College of

Education for Women, 16(1), 175-186. Retrieved from

https://www.iasj.net/iasj?func=issues\&jld=15\&uiLanguage $=$ ar

Abdul-Majeed, R.K. (2016). Taboo Words vs. Social Deixis: A Sociolinguitic Analysis of La Justice or The Cock that Crew: A Play from the Theatre of Ridiculous. Journal of College of Education for Women, 27(1), 400-414. Retrieved from https://www.iasj.net/iasj?func=issues\&jld=15\&uiLanguage $=$ ar

Abdul Zahra, S., \& Abbas, N.F. (2004). Cohesive Ties: Conjunctions. Journal of College of Education for Women, 15(2), 677-691.

DeLillo, D. (2007). Falling Man. New York: Scribner.

Duval, J.N. (2008). Introduction: The Power of History and the Persistence of

Mystery. In J.N.

Duval (ed.), The Cambridge Companion to Don Delillo (pp.1-10). Cambridge: Cambridge University Press.

Fairclough, N. (1989). Language and Power. London: Longman.

Gray, R. (2011). After the Fall American Literature since 9/11. Chichester: Wiley Blackwell.

Retrieved from

http://93.174.95/main/995000/bc9302e5095435b8ff5d4c8b5991852a/Richard\%20Gray\%28auth. \%29\%20-\%20After\%20the\%20Fall_\%20American\%20Literature\%20Since\%209_11-Wiley-

Blackwell\%20\%282011\%29.pdf

Keniston, A., \& Quinn, J.F. (2008). Introduction: Representing 9/11: Literature and Resistance. In A. Keniston, \& J.F. Quinn (eds.), Literature after 9/11 (pp.1-15). $\quad$ New York:

Routledge. Retrieved from http://blogs.shu.edu/english/files/2014/12/Literature-after-911.pdf

Knight, p. (2008). DeLillo, Postmodernism, Postmodernity. In J.N. Duval (ed.), The Cambridge

Companion to Don Delillo (pp. 27-40). Cambridge: Cambridge University Press.

Jeffries, L. (2010). Critical Stylistics: The Power of English. Basingstoke: Palgrave Macmillan.

Jeffries, L. (2014). Critical Stylistics. In M. Burke (ed.), The Routledge Handbook of Stylistics(pp. 408-420). Milton Park, Abingdon, Oxon: Routledge.

Jeffries, L. (2015). Textual Meaning and Its Place in a Theory of Language. In Topics in Linguistics, 15(1). $\quad$ Retrieved from http://eprints.hud.ac.uk/id/eprint/30099/1/\%255BTopics\%in\%2520Linguistics\%255D\%2520Text ual $\% 2520$ meaning $\% 2520$ and $\% 2520$ place $\% 2520$ in $\%$ a $\% 2520$ theory $\% 2520$ of $\% 2520$ language.pdf

Rowe, J.C. (2011). Global Horizons in Falling Man. In S., Olster (ed.), DON DELILLO Mao II, Underworld, Falling Man (pp.121-134). London: Continuum International Publishing Group. Simpson, P. (1993). Language, Ideology and Point of View. London: Routledge.

Tsiokou, K. (2017). Reading the Cityscape in Post- 9/11 Fiction: Urban Manifestation of Trauma and National Identity in Don DeLillo's "Falling Man" and Joseph O'Neill's "Netherland" (Master's thesis, The Aristotle University of Thessaloniki). Retrieved from http://ikee.lib.auth.gr/record/292553/files/GRI-2017-19784.pdf

Arab World English Journal for Translation \& Literary Studies

ISSN: 2550-1542 | www.awej-tls.org 